\title{
Agricultural Extension Approaches Influencing Uptake of Improved Sorghum Technologies in Embu County, Kenya
}

\author{
Evans L. Chimoita ${ }^{1, *}$, Cecillia M. Onyango ${ }^{2}$, John W.Kimenju ${ }^{2}$, Joseph P. Gweyi-Onyango ${ }^{3}$ \\ ${ }^{1}$ Department of Agricultural Economics, University of Nairobi, Kenya \\ ${ }^{2}$ Department of Crop Science and Protection, University of Nairobi, Kenya \\ ${ }^{3}$ Department of Agricultural Science and Technology, Kenyatta University, Kenya
}

Copyright $\mathrm{O} 2017$ by authors, all rights reserved. Authors agree that this article remains permanently open access under the terms of the Creative Commons Attribution License 4.0 International License

\begin{abstract}
Agricultural extension and technology transfer services play a vital role in disseminating research knowledge, skills and income generating strategies among the farming communities in Kenya. However, there exists a kind of disconnect between the amount of information and technologies developed in research centres and what is implemented by the farmers. The study evaluated the access and use of extension approaches in promoting uptake of improved sorghum technologies. The study systematically selected 129 farmers from four villages. Data on farmers' gender, age, household leadership, occupation and agricultural extension approaches were collected. The study revealed that $83 \%$ of the respondents were female out of which, $67 \%$ were engaged in improved sorghum production technologies. Besides, $56 \%$ young women (20 to 49 years) had embraced the growing of improved sorghum varieties Gadam and Sila 1. Further, mobile phones and radio services were the main means of access to the improved sorghum technologies. In addition, there was a strong positive correlation $(\mathrm{r}=0.122, \mathrm{P}=0.01)$ between extension approaches and uptake of the sorghum technologies. Besides government agricultural extension agents, visits to progressive farmers and/or research sites and use of demonstration plots contributed to $68 \%$ and influenced uptake of improved sorghum technologies. It was concluded that gender, family position and age of the farmer contribute to the uptake of improved sorghum technologies. Moreover, mobile phones and radio technologies play an important role in access of sorghum technologies.
\end{abstract}

Keywords Sorghum, Extension Approaches, Uptake, Technologies, Kenya

\section{Introduction}

Agricultural extension and information dissemination services in Kenya and most developing countries play a vital role in facilitating technology transfer, productivity and income generating knowledge among farmers Dixon, [4]. Besides service provision, extension agents from both government and private sector have over years engaged middle income farmers and resource-poor small scale farmers in disseminating modern technologies and knowledge. Further, they help farmers gain access to relevant information from various sources by evaluating and interpreting information based on farmers' past situations and experiences, Quion et al. [24].

The government extension service providers in Kenya include: Ministry of agriculture and related national government agencies in both national and county governments, and the Kenya Agricultural and Livestock Research Organization (KALRO) MoA, [17]. The private extension sector include, Non-governmental organizations (NGOs), faith-based organizations, farm inputs and various cash crops agencies such as tea, coffee, sugar-cane and wheat Wanyama, et al., [27]. There are various extension approaches in Kenya used in the dissemination of technologies including traditional 'top- down' approaches such training and visits $(\mathrm{T} \& \mathrm{~V})$ and farm visits. The top -down technology transfer and extension approaches paid more attention to trickle down or flow of information from research centres to extension agents and to the farmers Ngomane, [20]. The approach, because of its time-saving and limited bureaucracy, it is very common among the Kenyan government extension agents. However, there are alternative integrated research extension approach which are farmer friendly and puts emphasizes on 'bottom-up' communication from farmers to research stations through extension agents' and back to the farmer. The later approach is very common among the private extension agents in Kenya and worldwide

The integrated research extension approaches such as farmers field schools (FFS), participatory rural appraisal (PRA) emphasizes the importance of interactive, mutual learning between formal and informal knowledge/technology systems among stakeholders, Evenson and Mwabu, [7]. However, there has been an 
increased participation of the private sector extension agents in Kenya as compared to the government extension agents Munyua, [15] resulting in enhanced uptake of improved technologies on major exotic crops. Moreover, the private extension sector objectives manifest conflict with public extension sector and the existing government policies Kamau, [11]. As a result of the conflicting interests on commercial major crops, there has been negligence of improved technologies for neglected improved minor crops such as sorghum, millet, sweet potatoes and sim sim Munyua, [15], which play a significant role in food and nutrition security among marginal areas communities.

Documented evidence shows that, there exists improved technologies in the research institutions on the minor crops in Kenya and worldwide Erbaugh et al. [6]; ICRISAT [10]. For instance, the Kenya Agricultural Research Institute (KALRO) in collaboration with International Crops Research Institute for the Semi-Arid Tropics, have developed and released more than eight improved sorghum varieties suitable for arid and semi-arid regions of Kenya ICRISAT, [10]. However, these technologies are not reaching the farmers for utilization as a result of weak linkage between the government extension providers that are charged with the responsibility of ensuring that the technologies transfer and the farmers for utilization.

Moreover, the effectiveness of the government of Kenya extension sector provision has declined greatly during the last decade due to structural adjustment programmes (SAPs) and liberalization policies Munyua, [15]. The sector further faces constraints such as reduced and aged extension staff, low funding for operations and maintenance services, leading to weak information dissemination networks Kamau, [11] Therefore, the objective of this study was to characterize access and use of various extension approaches in enhancing uptake of improved sorghum technologies in marginal areas of Kenya

\section{Methodology}

\subsection{Study Site}

The study was conducted in Mbeere North Sub-County, Embu County, Kenya. The region's topography slopes from North West to South east direction. It is located on the East of Mount Kenya between coordinates $0^{\circ} 41^{\prime} 18^{\prime} \mathrm{N} 37^{\circ} 55^{\prime} \mathrm{E}$. The altitude of research site ranges from $500 \mathrm{~m}$ above sea level to about $1200 \mathrm{~m}$ above sea level. Temperature ranges from $15^{\circ} \mathrm{C}$ to $30^{\circ} \mathrm{C}$ with a mean temperature of $23^{\circ} \mathrm{C}$. The soils in the region fluctuate between sandy, blackish grey and reddish brown Matiri, et al. [14]. Mbeere North Sub-County has a bimodal pattern of rainfall with the long rains falling between March and June while short rains are experienced from October to December. The rainfall is, however, not very reliable and it ranges between $500 \mathrm{~mm}$ and $1100 \mathrm{~mm}$ per year with a mean of $800 \mathrm{~mm}$ rainfall per year. The sub county has population of approximately 516,212 inhabitants and the average farm sizes of 2.5 hectares Gachimbi, et al. [9].

\subsection{Methods}

The study employed a descriptive survey design suitable for describing information, data, events, perceptions and issues Mugenda and Mugenda, [18]. The study targeted a population of 2047 farmers documented by ministry of agriculture in Mbeere North report farming improved sorghum MoA, [17]. Multistage sampling technique was employed by dividing Sub-County into four village strata namely; Njura, Kangai, Njarange and Kiambungu villages of Embu County. Using the improved Kothari [12] formulae and procedure (Equation 1) a sample size of 129 farmers was achieved (Equation 2).Using previously pre-tested questionnaires with categorical and closed ended questions; one after every 16th farmer of the sampling frame obtained from the ministry of agriculture was selected and interviewed (Equation 3).

$$
n=\frac{Z^{2} \cdot P \cdot q \cdot N}{e^{2(N-1)}+Z^{2} \cdot P \cdot q}
$$

Where:

$\mathrm{n}=$ sample size,

$\mathrm{z}=$ standard variate at a given confidence level,

$\mathrm{p}=$ sample proportion of successes,

$\mathrm{q}=1-\mathrm{p}$

$\mathrm{N}=$ Size of population,

$\mathrm{e}=$ acceptable error (precision)

Hence, the most conservative number of farmers to be interviewed was:

$$
129.12(n)=\frac{1.96^{2}(0.5)(0.5) \cdot(2047)}{0.05^{2(2047-1)}+1.96^{2} \cdot(0.5)(0.5)}
$$

Where:

$\mathrm{n}=$ Sample size

The selection of the farmers was done by:

$$
\begin{gathered}
\mathrm{K}=\mathrm{N} / \mathrm{n}=2047 / 129=15.87 \\
\text { approximate every } 16 \text { th farmer }
\end{gathered}
$$

Where;

$\mathrm{K}=$ sampling interval

$\mathrm{N}=$ estimate of the population of smallholder farmers $\mathrm{n}=$ desired sample size

Primary data was gathered using pre-tested questionnaires. Data on household head, age, gender, education level, farmer's daily occupation, agricultural extension approaches and services accessed and utilized by farmers were collected. Secondary information on farm tenancy, population density, weather patterns, market outlets, quantities of sorghum harvested was obtained from the farmers' records, annual County agriculture reports, statistical abstracts, periodicals, journals, economic reviews and market reports. Data were analysed using Statistical Package for Social Sciences (SPSS version 20) to frequencies and percentages. Pearson's Moment correlation test was used to determine the significant differences and degree of association between variables. 


\section{Results}

Regarding the farmers' household characteristics, the study revealed that $83 \%$ of the respondents were female whereas $56 \%$ of the farmers were aged between 20 to 49 years, $27 \%$ of farmers aged between 50 to 60 years and $17 \%$ of farmers were aged $>60$ years (Table 1). The study findings also indicated that $79 \%$ of the household heads were men (Table 1).

Table 1. Farmers' household characteristics

Farmer characteristics (\% of respondents)

\begin{tabular}{ccccccccc}
\hline Gender & \multicolumn{3}{c}{ Age (Years) } & \multicolumn{5}{c}{ Family position } \\
\hline Male & Female & $20-49$ & $50-60$ & $\geq 60$ & $\begin{array}{c}\text { Male headed } \\
\text { Household }\end{array}$ & Spouse & Child & Other \\
\hline 17 & 83 & 56 & 27 & 17 & 79 & 13 & 07 & 01 \\
\hline $\mathrm{N}=117$ & & & & & & & &
\end{tabular}

In addition, the study findings indicated that $59 \%$ of the farmers had acquired secondary school education while $26 \%$ up to upper primary level (Table 2). The study findings also showed that $83 \%$ of farmers had spent less than 16 years in school and $4 \%$ had spent between one year and 8 years in school (Table 2).

Table 2. Farmers' household characteristics

Farmer characteristics (\% of respondents)

\begin{tabular}{ccccccccc}
\hline \multicolumn{2}{c}{ Education level } & \multicolumn{3}{c}{ Years in school } & \multicolumn{2}{c}{ Occupation } \\
\hline Primary & Secondary & Tertiary & $<8$ & $>11-15$ & $>16$ & Farming & Business & Employed \\
26 & 59 & 6 & 4 & 83 & 12 & 67 & 25 & 08 \\
\hline $\mathrm{N}=117$ & & & &
\end{tabular}

Further, the results revealed that $67 \%$ of farmers were involved in daily farming activities such as improved sorghum production activities and $25 \%$ of the farmers were involved in business activities. Regarding farmers access to sorghum technologies, the results indicated that $62 \%$ of the farmers were accessing and using the technologies along the sorghum value chains as compared to $38 \%$ that had accessed the technologies and not using in the field (Figure 1).

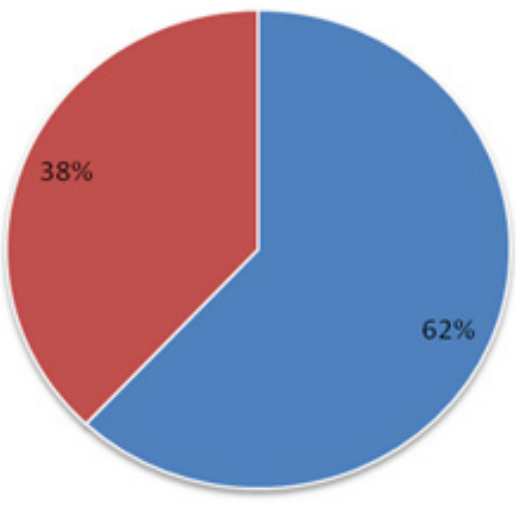

- Accessed and used information

- Accessed and did not use information

Figure 1. Access and use improved sorghum technologies information

The results also revealed a strong negative correlation $(\mathrm{r}=-0.124, \mathrm{p}=0.02)$ between $56 \%$ of the farmers' aged between 20 to 49 years accessing improved sorghum technologies in Mbeere North (Table 1).In addition, the study findings indicated that there was a strong positive correlation $(\mathrm{r}=0.180, \mathrm{r}=0.114)$ between family household heads and female farmers significantly $(\mathrm{p}=0.052, \mathrm{p}=0.010)$ influencing farmers access to improved sorghum technologies respectively (Table 3 ).

The strong negative farmers age correlation $(\mathrm{r}=-0.124)$ implied that, as farmers' age advanced, there was a corresponding decline in access to technologies.

However, there was no relationship and influence between occupation and education level variables and the uptake of improved sorghum technologies (Table 3).

Table 3. The relationship between household characteristics and the access to improved sorghum technologies

\begin{tabular}{cccccc}
\hline Variety uptake & Gender & Age & Family position & Education & Occupation \\
\hline Correlation $(\mathrm{r})$ & 0.114 & -0.124 & 0.180 & 0.072 & 0.076 \\
\hline Significance $\mathrm{P}=$ Value & $0.010^{* * *}$ & $0.02 * *$ & $0.052^{*}$ & 0.44 & 0.51 \\
\hline
\end{tabular}


In addition, the study findings revealed $68 \%$ farmers had taken up sorghum technologies out of which $58 \% 0$ of the farmers were exclusively growing the improved sorghum varieties as a mono crop (Figure 2).Besides, $10 \%$ farmers' had intercropped the improved sorghum varieties with other crops such as cassava, maize, cow peas, green grams varieties.
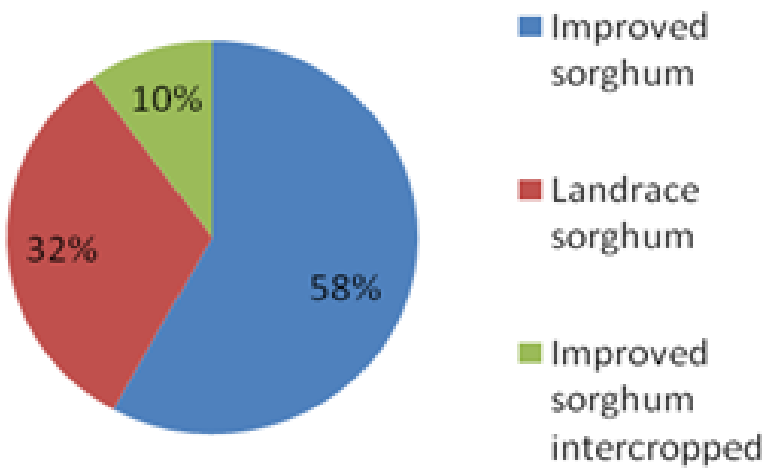

Figure 2. Farmers uptake of improved sorghum varieties

Regarding farmers access to extension approaches on improved sorghum technologies, the study findings showed that $99 \%$ farmers accessed production technologies through contact farmers and government agents approach, 93\% demonstration farms while $92 \%$ accessed information through ASK show visits approach (Table 4). Further, the results revealed that $93 \%$ farmers' accessed information by attending to demonstration plots while $92 \%$ got the information through ASK show visits (Table 4) during their field agronomic practice season. Further, during harvesting, farmers accessed harvesting and processing technologies through $92 \%$ farm or home visits, $85 \%$ demonstrations and $92 \%$ radio programmes (Table 4 ).

The results further showed that farmer's accessed marketing technologies through $94 \%$ office visits, $95 \%$ through face to face chats with market brokers and $85 \%$ mobile phone communication technologies (Table 4).
Table 4. Agricultural approaches promoting improved sorghum value chain

\begin{tabular}{|c|c|c|c|}
\hline \multirow{2}{*}{ Extension information sources } & \multicolumn{3}{|l|}{$\begin{array}{c}\text { Uptake } \\
(\%)\end{array}$} \\
\hline & $\begin{array}{c}\text { Producti } \\
\text { on }\end{array}$ & Processing & Marketing \\
\hline Contact farmer/ agents & 99 & 92 & 59 \\
\hline Office visits & 76 & 75 & 94 \\
\hline Telephone calls & 69 & 71 & 85 \\
\hline Demonstrations & 93 & 85 & 83 \\
\hline Face to face chats & 81 & 91 & 95 \\
\hline ASK shows & 92 & 92 & 90 \\
\hline Radio programmes & 94 & 92 & 83 \\
\hline Television shows & 76 & 78 & 80 \\
\hline Mobile phone SMS & 74 & 74 & 83 \\
\hline Internet & 52 & 64 & 85 \\
\hline Print media & 65 & 45 & 46 \\
\hline
\end{tabular}

The study revealed a relationship between the extension methods and the uptake of improved sorghum technologies along the value chain, indicating a strong positive correlation $(\mathrm{r}=0.124)$ between $99 \%$ government extension agents significantly $(\mathrm{p}=0.01)$ contributing to the uptake of improved sorghum technologies (Table 5). Moreover, the study findings revealed a positive correlation $(\mathrm{r}=0.124)$, between farmers accessing production technologies and significantly $(\mathrm{p}=0.00)$ contributing to the uptake of sorghum technologies (Table 5).

The study findings also showed a positive $(\mathrm{r}=0.124)$ correlation and a significant $(\mathrm{p}=0.00)$ relationship between farmers accessing marketing technologies and contributing to the uptake improved sorghum technologies (Table 5). Furthermore, the results indicated a significant $(\mathrm{p}=0.00)$ and positive relationship ( $\mathrm{r}=0.124)$ between farmers' accessing markets information through mobile phone and radio technologies contributing to the uptake of improved sorghum technologies (Table 5).

Table 5. Relationship between the extension approaches and the uptake of improved sorghum technologies along the value chain

\begin{tabular}{|c|c|c|c|}
\hline \multirow[t]{2}{*}{ Agricultural extension approaches } & \multicolumn{3}{|c|}{$\begin{array}{l}\text { Relationship between the extension approaches and the uptake of improved } \\
\text { sorghum technologies along the value chain }\end{array}$} \\
\hline & Production $\mathrm{P}=$ value & Processing $\mathrm{P}=$ value & Marketing $\mathrm{P}=$ value \\
\hline A.S.K shows & $0.01 * *$ & 0.058 & 0.06 \\
\hline Farm demonstrations & $0.01 * * *$ & 0.06 & 0.06 \\
\hline Contact farmers/agents & $0.01 * * *$ & 0.07 & 0.68 \\
\hline Community leaders & $0.01 * * *$ & 0.05 & 0.07 \\
\hline MoA Extension agents & $0.01 * * *$ & 0.05 & 0.06 \\
\hline Farmers field groups & $0.01 * * *$ & 0.05 & $0.02 * *$ \\
\hline Organizational visits & $0.01 * * *$ & $0.02 * *$ & 0.06 \\
\hline Radio services & $0.01 * * *$ & 0.06 & 0.06 \\
\hline Print media & $0.02 *$ & 0.06 & 0.07 \\
\hline Mobile phones & $0.01 * * *$ & 0.05 & 0.05 \\
\hline
\end{tabular}

Statistical aassociation significance levels $* * * \mathrm{p}<0.01 \mathrm{P}<0.05 \mathrm{n}=117$ 


\section{Discussion}

The study revealed that $83 \%$ of the respondents were female out of which $67 \%$ were engaged in sorghum production technologies. Contrary in terms of gender, the current the study findings indicated that $79 \%$ of respondents were male household heads whereas $13 \%$ were spouse of the household heads. The current results could be indicator that sorghum production in Mbeere North is a preserve and practiced by female farmers. In similar study Muui et al., [19] asserted that that most female household members were engaged in production of sorghum in arid regions of Kenya. Further, majority of the household heads male members of the family are majorly involved in family decision making process. The decision making on adoption of new technologies by the male dominated household heads may have a minimal influence on the uptake of the technologies. The assertion is supported by the fact that most male farmers engage in activities outside their homesteads during the day whereas female counterparts access information and engage on farm agricultural activities. Related to this study Finda, [8] indicated that rural women in particular are responsible for half of the world's food production and produce between $60 \%$ and $80 \%$ of the food in most developing countries. This was found to be the case in Mbeere where $67 \%$ of the women were involved in exclusive sorghum production.

In addition Okello, et al., [21] asserted that women and youth share a range of information, including agricultural and entrepreneurship technologies through social networks and mobile phone conversations more than their male counterparts. Further, Okello, et al., [21] indicated that higher information sharing contributed to increased adoption of new technologies among women than male counterparts contributing to higher uptake rates. Besides, Cheplogoi and Udoto, [2] documented that women group activities and household income levels contribute immensely towards households' food security. In a further study, Oyugi, et al., [22] documented those women farmers are frequently underestimated and overlooked in development strategies despite their contribution to global food security. Further, women contribution to agricultural development has led to global concern, which in turn has led to a special focus on women in development issues. This scenario could be explained by the fact that women from the Mbeere region access production knowledge among their peers and other social networks. The current study indicated 57\% farmers had spent over 16 years in school whereas 58\% farmers' had acquired education up to secondary school level. The study results further revealed that $56 \%$ of farmers aged between 20 to 49 youthful years were engaged in improved sorghum production. The study findings implies that farmers in Mbeere north had basic educational requirements and capable of acquiring new knowledge and skills. Related to this study, Czapiewshi et al., [3] asserted that the higher the youthful literacy levels and age of any given household member the higher the probability of adoption of various enterprises. Further, Doss et al., [5] study demonstrated that, whereas age was positively associated with the use of improved varieties of maize and wheat, literacy levels of farmers contribute greatly towards adoption. Moreover, Piccoli et al., [23] study supported the fact that education levels improves the farmers' capacity to comprehend the benefits of new technologies including new innovations and improved technologies. Moreover, Piccoli et al., [23] established that education level of an individual is very vital in information acquisition and increases the individual's capacity to interpret and utilize the acquired information.

The current study further showed that majority $56 \%$ of the farmers had spent over 16 years in school. In an argument that supports this view Konopski, [13] study revealed that farmers who have spent less than ten years of schooling are less capable of acquiring and utilizing information from the ICT/internet services. In addition, Salasya et al., [26] reported that access to education and institutional extension advice significantly influences the uptake and use of farm inputs on improved maize production. The study results showed that $88 \%$ farmers accessed production technologies through bench marking organizational visits such as ASK shows and farm visits. The association between organizational visits and uptake of improved technologies results further indicated a significant $(p=0.02)$ contribution of influence of uptake of improved sorghum varieties.

Further there was a strong association $(\mathrm{P}=0.01)$ between government extension agents and uptake of improved sorghum varieties. The association between mobile phone communication and uptake of improved sorghum technologies respectively revealed significant $(\mathrm{p}=0.00)$ relationship on uptake of improved sorghum technologies. Related to this study Muui et al., [19] reported that farmers with basic knowledge on available institutional assistance can contribute to sorghum varieties production. Moreover, the positive uptake results could be attributed to that government agriculture extension agents greatly influencing and enhancing production skills in uptake of improved sorghum technologies. This could be further attributed that the government agents because of availability and proximity of agents to farmers. Moreover, it was revealed that farmers still regard government agents important when accessing information and decision making on uptake of improved sorghum varieties production and other services. Related to this study, Robinson and Maganga, [25], emphasized the need for the establishment of strong linkages and institutional packages between farmers and extension officers on various agricultural messages. The study findings showed that farmers acquired marketing techniques for enhanced improved sorghum products through 96\% local station radio services, $98 \%$ farmers through face to face chats with market brokers and $75 \%$ mobile phone technologies. The current study revealed that majority of farmers accessed marketing services via mobile phones by linking with brokerage markets. The most revealed market avenues were EABL and local markets existing between farmers and 
buyers. Possibly this can be explained by the fact that mobile phones are more versatile than the internet emails and websites hence can be used to access several services such as telecommunication services. Tata and McNamara [16] asserted that ICTs supplement rather than replace traditional extension methods. Further, the use of ICTs by extension agents' has been documented to result into personal benefits and increased professional productivity and sustained traditional interaction between farmers and agents. Additionally, the current study resonates well with Word Bank [28] study which indicated that ICTs improve adoption of agricultural technology by supporting farmer learning, problem solving, and accessibility to profitable markets for their products. This could be attributed to the fact that mobile phones and radio services do not require much literacy skills to operate. Further, such technologies are affordable and are accessible to the rural inhabitants. The communication authority of Kenya (CAK) [1], has documented that there are more mobile phones than internet subscribers.

\section{Conclusions}

It was concluded that gender, age and family position of the farmer contribute to promoting uptake of improved sorghum technologies. Mobile phones technology and radio services play an important role in enhancing uptake of improved sorghum varieties. Further, the government extension agents strongly influence farmers' uptake of improved sorghum technologies. The study recommended that youth and women be empowered through education.

Besides, the governments recruit and facilitate extension agents as well as integrate modern information technology in disseminating agricultural technologies on improved sorghum technologies.

\section{Acknowledgements}

I must thank our almighty God for providing life, good health, patience, strength and wisdom during the writing process. I also appreciate the great financial support towards thesis writing from Association of African Universities, Ghana and the University of Nairobi, Kenya.

\section{REFERENCES}

[1] Communication Authority of Kenya (CAK) (2014). Quarterly sector statistics report, Third quarter of the financial year 2013/14, Nairobi, Kenya

[2] Cheplogoi, S. K., and Udoto, M. (2013): Contribution of Agriculture Related Activities of Women Groups to Household Income Levels and Food Security in Barwessa Division, Baringo County, Kenya, International Journal of Advanced Research , 1 (8), 85-92
[3] Czapiewshi, K,. R; Banski J, Bednarek-szczepanska. M., Konopski M.(2013). The use of ICT in Mazovian Agriculture: In; P. Chmielinski, A. Baer. Nawrocka (Eds), Knowledge as a factor of rural development, Rural areas and Development 10: 45-574.

[4] Dixon, J. (2010). Operationalizing participatory research and farmer-to-farmer extension: The Kamayoqin Peru: RoutledgeInforma Ltd, Registered in England and Wales Registered Number: 1072954 Registered office: Mortimer House, 37-41 Mortimer Street, London W1T 3JH, UK.

[5] Doss C.R. (2003).Understanding Farm Level Technology Adoption: Lessons Learned from CIMMYT's Micro surveys in Eastern Africa. CIMMYT Economics Working Paper03-07. Mexico, D.F.: CIMMYT.

[6] Erbaugh, J. M., Donnermeyer, J., Kibwika, P. (2010): Evaluating farmers' knowledge and awareness of integrated pest management (IPM): Assessment of the IPM collaborative research support program in Uganda. Journal of International Agricultural and Extension Education, 8(1), 47-53.

[7] Evenson, R. and G. Mwabu (1998): The effects of Agricultural Extension on Farm yields in Kenya. Economic Growth Center Discussion Paper No. 798. Yale

[8] Finda, B. J., (2009). Gender and Social Issues of Rice-Based Farmers during the 2005/2006 Cropping Season. In Agricultural Innovations for Sustainable Development. Contributions from the Finalists of the African Women in Science Competition. Volume 2 Issue 1. The technical Report for CTA/ATPS/AGRA/FARA/NEPAD/RUFORUM.

[9] Gachimbi, L., Kamoni, P., Wanjogu, S. N, Macharia P. N and Gicheru, P.(2007): Land Use Practices In Mbeere District: Biophysical And Socio Economic Challenges, Copping Strategies And Opportunities: A Baseline Survey Report 10. ICRISAT, (2006): International Crops Research Institute for the Semi-Arid Tropics (ICRISAT), Eastern and Southern Africa Region, 2005-2006 Highlights, Nairobi, Kenya, ICRISAT, www.icrisat.org/Kenya, Retrieved 27th April 2015

[10] ICRISAT, (2006): International Crops Research Institute for the Semi-Arid Tropics, Eastern and Southern Africa Region, 2006-2005 Highlights, Nairobi, Kenya, ICRISAT, www.icrisat.org/Kenya, Retrieved $27^{\text {th }}$ April 2015

[11] Kamau, F. (2006): Challenges in Provision of Agricultural Extension Services in Kenya: An Evolution From Public to Public- Private Partnership, Paper presented during 10th Africa Forum, Windhoek, Namibia, 30th Oct - 3rd Nov. 2006

[12] Kothari C. R (2010): Research Methodology: Methods and Techniques (2nd revised edition)

[13] Konopski M. (2013). The use of ICT in Mazovian Agriculture: Knowledge as a factor of rural development, Rural areas and Development 10: 45-574.

[14] Matiri, F. M., Ouma, J. O and Gitari, J. N. (1999). Assessment of adoption of improved crop varieties in the drylands of Eastern Kenya- a case study of Tharaka District and Mbeere Districts. In: Sutherland, J. A (Ed.), Towards increased use of demand driven technology, end of project conference, 23rd 26 th March 1999, KARI and DFID, Nairobi.

[15] Munyua, H. and Stilwell, C. (2010). A mixed qualitative and quantitative participatory methodology. A study of the agricultural knowledge and information system (AKIS) of small-scale farmers in Kirinyaga district, Kenya 
[16] Tata, J. S and McNamara, P. E (2016). Social Factors That Influence Use of ICT in Agricultural Extension in Southern Africa, Journal of Agriculture, accessed 23rd August 2016

[17] Ministry of Agriculture (2010): The Annual Report, Crop Development Division, Mbeere Division, Embu County, Kenya.

[18] Mugenda, O. M, and Mugenda, A., G. (1999): Research methods - Quantitative and quantitative approaches. Nairobi: Acts Press

[19] Muui C. W, Muasya R. M, Kirubi D. T. (2013): Baseline Survey on Factors Affecting Sorghum Production and Use in Eastern Kenya; African Scholarly Science Communication Trust, Nairobi Kenya

[20] Ngomane T. (2004): From a Deficit-Based to an Appreciative Inquiry Approach in Extension Programs: Constructing a Case for a Positive Shift in Current Extension Intervention Paradigm; Journal for International Agricultural Extension, 17(3).

[21] Okello J., Ofwona-Adera, E., Mbatia, O.L.E and Okello R. M (2010): Using ICT to integrate small holders farmers into agricultural value chain; the case of DvuMNef project in Kenya: International Journal of ICT Research development in Africa, Vol, 1:23-37.

[22] Oyugi M. A, Amdavi D. M., Nandi J., O., M., and Ombati J., M. Gendered roles in Bambara Production Activities: A case of Butere and Mumias Districts, Kenya. International Journal of Agriculture and Crop Sciences. Available online at www.ijagcs.com IJACS/2014/7-15/1514-1518

[23] Piccoli, G., Ahmed, R., Lives, B., (2001): Web based virtual learning environments; A Assessment of framework in Basic IT skills Training, MLS Quarterly, Vol, 25:40-426

[24] Quizon, J., Feder, G., \&Murgai, R., (2001): Fiscal sustainability of agricultural extension: Proceedings of the 3rd General Workshop of the Pan-African Striga Control Network Harare, Zimbabwe

[25] Robinson, E. J., and Maganga F. (2009): The Implications of Improved Communication for Participatory Forest Management in Tanzania, African Journal of Ecology, 47: 171-178

[26] Salasya, B., Mwangi, W., Odendo, M., Mwabu, D., Diallo, A. and Odongo, O. (2006). Factors influencing the adoption of stress tolerant Hybrid maize (WH 502) in Western Kenya. CIMMYT, Nairobi

[27] Wanyama, J. M., Njue, E. K. and Kidula, N. L. (1996). Evaluation of sorghum technology adoption levels in Homa Bay district. In: Fungoh, P. O and Mbadi, G.C.O., Focus on Agricultural Research for sustainable development in a changing Economic Environment. Proceedings of the 5th KARI Scientific Conference, 14th -16th October 1996. KARI, p. 360-369.

[28] World Bank, (2009). "Information and Communication for Development (IC4D) Extending Reach and Increasing Impact”., Report 